\title{
Perception of Elementary School Teacher Education Students of Universitas Negeri Malang towards the Main Parts of Plants
}

\author{
Sri Estu Winahyu \\ Elementary School Teacher Education \\ Universitas Negeri Malang \\ Malang, Indonesia \\ sri.estu.fip@um.ac.id
}

\author{
Harti Kartini \\ Elementary School Teacher Education \\ Universitas Negeri Malang \\ Malang, Indonesia \\ harti.kartini.fip@um.ac.id
}

\author{
Lilik Bintartik \\ Elementary School Teacher Education \\ Universitas Negeri Malang \\ Malang, Indonesia \\ lilik.bintartik.fip@um.ac.id
}

\begin{abstract}
This study aims to describe students' perceptions of the main parts of plants (root, stem, and leaf). This type of descriptive research, with data collection through the semiopen questionnaire. Data analysis used a descriptive quantitative method. The results of the study found that students' perceptions of the main parts of plants have not been entirely scientifically correct. Perception errors occur on the concept of taproot on roots of mangrove plants, determination of carrot stems, complete leaf arrangement and vein in banana plants. Thus it can be concluded that most students did not have a scientifically correct perception of the major parts of plants. Therefore, the recommendation from this study is that lecturers should use factual examples during their learning.
\end{abstract}

Keywords—perceptions, plant, student, elementary school teacher education

\section{INTRODUCTION}

One of the aims of organizing elementary school teacher education is to produce educational scholars who are ready to be educated to become professional elementary school teachers [1]. Professional teachers are not only required to master the material but also need to have competence in the field of skills in creating conducive learning and good character. Professional teachers are teachers who know deeply about what is taught, are able to teach it effectively, efficiently, and have a good personality [2]. It is reflected that in addition to having professional competencies in the effective and psychomotor fields, professional teachers must also master the material or mastery in the cognitive field.

Mastery in the cognitive field needs to be possessed because elementary school teacher education carries out the mandate to guide students to acquire basic knowledge as a tool to know their environment scientifically. Based on its responsibilities, elementary school teacher education students as prospective elementary school teachers must have extensive knowledge and correct understanding of the concepts learned. For this reason, elementary school teacher education students need to be equipped with good basic concepts from various disciplines, one of which is through natural science subject.

The natural science subject is one of the science groups that address the problem of living things, which includes plants, animals, and humans [3]. The purpose of this course is to provide students with the competence to use science process skills and scientific methods to understand living things and their life processes [1]. From this goal, it is implied that students are required to be able to understand the concepts of science in various ways.

To achieve this goal, it is necessary to design learning activities that provide real experience in the concept discovery process. Thus, students are required to have the correct scientific concepts about the natural surroundings, so that the possibility of misconception in applying in elementary school can be avoided. To equip mastery of material, elementary school teacher education students need an effective and efficient learning process in lectures [4]. For this purpose, learning activities need to be designed with attention to the prior knowledge of students

Lecture needs to know students' prior knowledge in order to help students learn more effectively. Learning become more meaningful if students are given experiences that help to connect with the knowledge they have before. The prior knowledge possessed by the learner plays an important role when they learn about something that is already known [5].

Based on the learning experience, it was found that there was a misconception regarding plant parts. An example of this misconception was found that students argued about the crown part of Bougainvillea was brightly colored (red, purple, and orange). This is the type of misconceptions because in fact the bright parts of this flower are the modification of leaves or supporting leaves.

The previous findings above are in accordance with the results of the other research which concluded that the initial knowledge of students of elementary school teacher education about the organism and the life processes was categorized as lacking [4]. Another fact from the results of research Winahyu and Kartini that the conception of teachers on the true part of Bougainvillea flowers scientifically was only found in $29 \%$ of teachers [6]. This finding is quite alarming, considering elementary school teachers have a fundamental role in helping students discover scientific concepts. If the conception of the teacher is not scientifically correct, it is feared that errors will occur in the students.

Based on the findings above, it is necessary to anticipate early, so that there will be no misconceptions among elementary school teacher education students. One of the efforts of conducting research is to uncover elementary school teacher education students' perceptions of the main 
parts of the plant. This research is done in order to gather an overview of students' perceptions before taking the natural science course. The findings from the results of this study are expected to be used to design learning activities better, so that misperceptions about the concepts of science, especially about the main parts of plants can be minimized.

\section{METHOD}

This research is a descriptive research that aimed to describe the findings systematically and accurately about students' perceptions of the main parts of plants. This research was conducted on students of elementary school teacher education in the first semester in Universitas Negeri Malang. Determination of students is based on the consideration that first semester students have not programmed the natural science in this major.

The sample was determined by the technique of nonproportional random sampling area because the population consisted of 3 sub-populations spread in 3 locations (PP1, PP2, and PP3). All students are designed as respondents without taking into account the number of students from each offering so that non-proportional techniques are used. With this technique, 246 samples were obtained.

The instrument used was a semi-open questionnaire with 20 items, to collect student conception data about the main parts of the plant. Instrument validation is done with content validity, which matches the questions of the instrument grid and being asked for the experts' opinion. Validation results are used to revise the instrument.

The data obtained were analyzed using the descriptive quantitative method and be presented in percentages. Furthermore, the respondents' data which allegedly occurred misconceptions were analyzed using the same method to find out which concepts are misconceptions. Next, the data is classified based on the type domain, analyzed, and interpreted based on the theory referred to. Interpretation results are used to draw conclusions and describe elementary school teacher education student perceptions of the main parts of the plant.

\section{RESULT AND DISCUSSION}

The description of student perceptions of the main parts of the plant varies. This means that there is a perception that is scientifically correct, but there are those that are not true. The description of student perceptions of the main parts of the plant can be seen in Table 1.

Based on the data in table 1 above, it can be seen that student perceptions of the main parts of plants are still diverse. This means that there is something that is scientifically correct, but there are also many items that have not been found scientifically correct. From these data, it appeared that the perception of the root system of wild plants that grow on the surface of the soil, which is scientifically correct is only found in 67 students $(27.24 \%)$. The remaining students as many as $179(77.76 \%)$ students are still not correct. When they were asked about the stems in carrots, only $54.07 \%$ of students answered correctly. This fact showed that not all students know the stem on carrot plants.
Diverse perceptions are also found in the concept of leaves. In the question item about the sample of plants that have complete leaves, only 27 students (10.98\%) were able to answer correctly, namely the leaves owned by banana plants. As for the leaves of mango, jackfruit, and corn expressed by $80.02 \%$ of respondents as examples of complete leaves. Even though it should not include a complete leaf because it does not have one of the complete leaf characteristics which have a midrib.

Students also asked questions about the arrangement of veins in banana leaves. Of all respondents, there were only 71 people $(28.86 \%)$ who had a true perception of banana leaf veins and as many as 175 people $(71.14 \%)$ had wrong perceptions. For cactus leaves, more than half $(66.67 \%)$ of people have recognized them correctly. In this case, students stated that the cactus plants that act as leaves are thorns.

Based on the analysis of the data after tabulation and mapping in Table 1, it is obtained that students' perceptions of the main parts of plants have not been entirely scientifically correct. Misperceptions were found both in the roots, stems, and leaves.

TABle I. St St Sthents' Perception of The Main Parts of Plants

\begin{tabular}{|c|l|l|c|c|c|}
\hline No & Question & \multicolumn{1}{|c|}{ Answer } & Total & $\%$ & Category \\
\hline 1. & Roots of & a. Fibers & 40 & 16.26 & False \\
& mangroves on & b. Ride & 136 & 55.28 & False \\
& the ground & c. Support & 67 & 27.24 & True \\
& surface & d. Breath root & 3 & 1.22 & False \\
\hline 2. & Examples of & a. Papaya & 20 & 8.13 & False \\
& fibers rooted & b. Spinach & 105 & 42.68 & False \\
& plants & c. Kale & 78 & 31.71 & False \\
& & d. Talas & 43 & 17.48 & True \\
\hline 3. & Examples of & a. Water henna & 22 & 8.94 & True \\
& tapered plants & b. Peanut & 25 & 10.6 & True \\
& & c. Rice & 11 & 4.47 & False \\
& & d. Papaya & 188 & 72.43 & True \\
\hline 4. & The base of & a. Leaf & 112 & 45.53 & False \\
& the carrot is & b. Stem & 133 & 54.07 & True \\
& named & c. fruit & 1 & 0.40 & False \\
\hline 5. & The center of & a. Stem & 42 & 17.07 & False \\
& the carrot is & b. Tubers & 117 & 47.56 & True \\
& named & c. Fruit & 87 & 35.37 & False \\
\hline 6. & The base of & a. Root & 239 & 97.15 & True \\
& the bottom of & b. Root cap & 7 & 2.85 & False \\
& the carrot & & & & \\
\hline 7. & Examples of & a. Mango & 174 & 70.72 & False \\
& complete & b. Banana & 27 & 10.98 & True \\
& leaves & c. Jackfruit & 38 & 15.45 & False \\
& & d. Corn & 7 & 2.85 & False \\
\hline 8. & Banana leaf & a. Curved & 72 & 29.27 & False \\
& veins & b. Straight & 86 & 34.96 & False \\
& arrangement & c. Pinnate & 71 & 28.86 & False \\
& & d. Parallel & 17 & 6.91 & True \\
\hline \multirow{2}{*}{9.} & Leaves on the & a. Stem & 51 & 20.73 & False \\
& cactus & b. Thorn & 164 & 66.67 & True \\
& & c. Flower & 31 & 12.60 & False \\
\hline
\end{tabular}

The root generally functions to strengthen the development of plants. In addition, the root also functions to absorb water and mineral dissolved in the soil. Roots on certain plants have a function to store food reserves or as a food storage area known as root tubers [7]. The concept of the roots has been introduced starting in elementary school. This shows that the respondents as a whole have already studied the root, but when faced with questions about the 
root systems of the plants around them, incorrect answers are still found. For example, when asked about the unusual root that appears on the surface of the ground, more than half of the students stated tap-root. Even though the correct answer is the root support.

According to morphology, the roots that grow on the surface of the soil in herbaceous plants are called the supporting roots. Supportive roots are roots that grow from the bottom of the stem in all directions and as if supporting the stem so as not to fall [8]. This fact shows that the students' conception of the root concept that has been studied before is not yet strong. This should not happen, given the root problem has been discussed since elementary school to the high school level. When traced to some students why answer that, the reason is that someone has forgotten and there are those who interpret based on their understanding. The existence of this fact should not be allowed, because misperceptions can result in errors in the respondents' perception of the stem are less than the perception of the root. This is based on the fact that half of the students $(54.07 \%)$ have been able to perceive correctly about the stems of carrots. This fact shows that the stem problem is well understood by half of the respondents. However, it still needs strengthening for other students because $113(45.03 \%)$ students still do not recognize the stem on carrots.

This is presumably because so far students have never acknowledged carrot plants directly and completely with their stems and leaves. Based on his experience, students often see carrots ready to be cooked without stems and leaves, so that they know tubers better than the stems. Although the tuber is better known than the stem, it turns out that based on the data obtained, it was found that $52.04 \%$ of students recognized carrot tubers as fruit and stems.

Based on data findings regarding leaves as part of the plants, there are still misperceptions about the arrangement of bones in banana leaves. Almost all students, namely 93.09\% stated that the leaf bones of banana plants are curved, straight and parallel. Only a small part of the students surveyed $(6.91 \%)$ was correct with the answer was pinnate. This finding reinforces the fact that student conception of leaf bone composition is also not strong. This statement is supported by data that students still do not understand that complete parts of the leaves consist of midribs, stems, and leaves. Of the total data collected, only $10.98 \%$ of students perceived correctly that banana leaves are complete leaves. The rest of the students stated that the complete leaves were, for example, corn, jackfruit, and mango.

In the concept of leaves on cactus plants, half of the students have been identified did not have misconceptions towards this issue. Students stated that in cactus plants that function as leaves are thorns. This is true, because not all leaves have complete parts [9]. Leaves in plants in terms of shape, veins structure and width of the leaves vary greatly. Observing the findings described above illustrates that students' perceptions of the main parts of plants that include root, stems, and leaves are still not strong.
A person's perception of a particular object or phenomenon may not be the same between individuals, even though the object being observed is the same. This can happen because each individual has different experiences and different perspectives in interacting with their environment [10]. Through experience, intuition is formed in the brain and "student theory" of natural knowledge [11]. As for Piaget's view that intellectual structures are formed when individuals interact with their environment [12]. Of the two opinions explained that each individual when interacting with his environment either through observation or other activities, in his brain will occur the process of forming new knowledge.

The process of forming new knowledge can be explained through cognitive psychology. According to Piaget cognitive processes in each individual occur through assimilation and accommodation. Every individual has a new experience or new information will be accepted by his brain structure [13]. In the future, there will be a merger by linking new information with the knowledge that has been owned. The results of information processing that occur through assimilation and accommodation, in the form of a structure of building new concepts in the minds of students.

\section{CONCLUSION}

Based on the findings and discussion, it can be concluded that: Student perceptions of the main parts of plants consisting of roots, stems, and leaves, are not yet scientifically correct. Misperceptions were found in the concept of supporting roots in uncultivated plants. Correct perception is found in the concept of plants that have taproot systems. Errors are also found in the determination of carrot stems. In addition, most students do not have the correct perception of complete leaf samples and banana leaf bone arrangement. The perception that is correct, is found by most students of the leaves on cactus plants.

Furthermore, in order to offer benefits for the improvement of science courses in elementary school teacher education, there are suggestions were made for elementary school teacher education lecturers, especially in the natural science course coaches so that in lectures, students should be given direct experience to find concepts about the surrounding plant parts. If there is found some students having wrong perceptions, remediation is immediately carried out for them. For elementary school teacher education students, it is recommended to study the main parts of the plant using various sources, because there are infinite variations in various parts of plants in the environment. In addition, it should be conducted research and direct observation of the object so that misperceptions can be avoided.

\section{REFERENCES}

[1] FIP-UM, Katalog FIP UM jurusan kependidikan dan sekolah dasar. Malang: FIP Universitas Negeri Malang, 2015.

[2] A. Bukhari, Guru profesional. Bandung: Alfabeta, 2014.

[3] J. L. Anderson, J. P. Ellis, and A. M. Jones, "Understanding early elementary children's conceptual knowledge of plant structure and function through drawings," CBE-Life Sci. Educ., vol. 13, no. 1981, pp. 375-386, 2014. 
[4] L. Bintartik, H. Kartini, and S. E. Winahyu, Eksplorasi pengetahuan awal (prior knowledge) mahasiswa PGSD tentang materi IPA pada tahun pelajaran 2015-2016 di Universitas Negeri Malang. Malang: LP2M UM, 2016.

[5] Suyanto and K. E. Kasiyani, Model-model pembelajaran. Malang: Kementerian Pendidikan Nasional Universitas Negeri Malang, 2010.

[6] S. E. Winahyu and H. Kartini, "Konsepsi siswa dan guru tentang konsep-konsep IPA di SD sekota Malang," J. Teor. dan Prakt. Penelit., vol. 18, no. 1, 2006.

[7] W. J. Lucas et al., "The plant vascular system: evolution, development and functions," J. Integr. Plant Biol., vol. 55, no. 4, pp. 294-388, 2013.

[8] G. Tjitrosoepomo, Morfologi tumbuhan. Yogyakarta: Gajahmada University Press, 2007.
[9] K. V Krishnamurthy, S. Labs, B. Bahadur, S. J. Adams, S. Labs, and P. Venkatasubramanian, "Origin, Development and Differentiation of Leaves," Plant Biol. Biotechnol., vol. 1, no. March 2016, pp. 153$175,2015$.

[10] M. N. Kastanakis and B. G. Voyer, "The effect of culture on perception and cognition : a conceptual framework," J. Bus. Res., vol. 67, no. 4, 2014.

[11] E. V. D. Barg, Miskonsepsi fisika dan remidiasi. Salatiga: Universitas Kristen Satya Wacana, 1991.

[12] R. W. Dahar, Teori-teori belajar. Jakarta: Erlangga, 1998.

[13] E. M. W. Simatwa, "Piaget's theory of intellectual development and its implication for instructional management at pre- secondary school level," Educ. Res. Rev., vol. 5, no. July, pp. 366-371, 2010. 